\title{
$\mathrm{RhD}$ 음성 산모에서의 항-G 항체 동정: 국내 첫 보고
}

최수인 ${ }^{1, \star} \cdot$ 윤선주 $^{1, \star} \cdot$ 서지영 ${ }^{1} \cdot$ 천세종 $^{1} \cdot$ 오수영 ${ }^{2} \cdot$ 조 덕 ${ }^{1}$

성균관대학교 의과대학 삼성서울병원 진단검사의학과 ${ }^{1}$, 성균관대학교 의과대학 삼성서울병원 산부인과 ${ }^{2}$

\section{Identification of Anti-G in Pregnant Women with RhD Negative Blood: The First Case in Korea}

\author{
Sooin Choi ${ }^{1, *}$, Sun Joo Yoon ${ }^{1, *}$, Ji Young Seo ${ }^{1}$, Sejong Chun ${ }^{1}$, Soo-Young $\mathrm{Oh}^{2}$, Duck Cho ${ }^{1}$ \\ Department of Laboratory Medicine and Genetics, Samsung Medical Center, Sungkyunkwan University School of Medicine ${ }^{1}$, \\ Department of Obstetrics and Gynecology, Samsung Medical Center, Sungkyunkwan University School of Medicine², Seoul, Korea
}

Anti-G positivity can be misinterpreted as the presence of anti-D or -C antigen in an antibody identification test, as this antibody is known to show agglutination to $\mathrm{D}$ or $\mathrm{C}$ antigen-positive red cells. Correct identification of anti-G is important in pregnant women, as prenatal care or the need for RhIG administration can vary between anti-D and $-\mathrm{C}$ versus anti-G cases. We recently encountered a D-negative case with suspected anti-D and -C, which was ruled out by adsorption and elution tests, and ultimately confirmed the presence of anti-G. The pregnant woman was a 33-year-old patient with cde $\mathrm{Rh}$ phenotype with a previous history of spontaneous abortion, followed by administration of RhIG. The spouse's Rh phenotype was CDe. Initial antibody identification test showed $2+$ positivity to $\mathrm{C}$ (homozygotes and heterozygotes) and trace to $1+$ positivity to $\mathrm{D}$. Upon additional adsorption and elution with ROr (cDe/cde) and r'r (Cde/ cde) red cells, we identified the antibody present in the patient's serum as anti-G. The patient is currently under close follow-up monitoring for anti-G titer using antibody titer testing with both $\mathrm{CDe}$ and $\mathrm{CcDEe}$ red cells. Periodic fetal cerebral Doppler examination is being carried out without evidence of fetal distress. (Korean J Blood Transfus 2017;28:304-310)

Key words: RhD negative, Hemolytic disease of fetus and newborn, Rhogam, Anti-G, Absorption and elution

\section{서 론}

$\mathrm{Rh}$ 혈액형 군에 속하는 G 항원은 1958년 Allen과 Tippett [1]에 의해 처음 기술되었다. $\mathrm{G}$ 항원은 $R H D$
나 $R H C E$ 유전자 엑손 2에 의해 발현되므로 $\mathrm{D}$ 또 는 $\mathrm{C}$ 항원 양성 적혈구에서 표현되고, $\mathrm{D}$ 와 $\mathrm{C}$ 항 원이 모두 음성인 적혈구(예, ce)에는 표현되지 않는다[2]. G 항원의 이러한 특징 때문에 비예기

Received on November 24, 2017. Revised on December 8, 2017. Accepted on December 12, 2017

Correspondence to: Duck Cho

Department of Laboratory Medicine and Genetics, Samsung Medical Center, Sungkyunkwan University School of Medicine, 81 Irwon-ro, Gangnam-gu, Seoul 06351, Korea

Tel: 82-2-3410-2403, Fax: 82-2-3410-2719, E-mail: duck.cho@skku.edu, ORCID: http://orcid.org/0000-0001-6861-3282

*Sooin Choi and Sun Joo Yoon contributed equally as co-first authors.

(C) This is an Open Access article distributed under the terms of the Creative Commons Attribution Non-Commercial License (http://creativecommons.org/licenses/by-nc/4.0) which permits unrestricted non-commercial use, distribution, and reproduction in any medium, provided the original work is properly cited.

Copyright (C) 2017 The Korean Society of Blood Transfusion 
항체를 동정할 때 항-G 단독항체, 항-D와 -C 복합 항체, 그리고 항-G, -D와 -C 복합항체의 감별이 어렵다. 해당 소견을 보이는 환자에게 수혈이 필 요한 경우에는, 모두 ce 표현형의 D 음성인 혈액 을 수혈하면 안전하므로 항-D와 항-C 복합항체 또는 항-G 항체인지의 감별은 필수적이지는 않 다[3]. 하지만 임산부의 혈액에서 확인되었을 경 우에는, D 항원 반응성이 항-G 항체에 인한 것인 지 감별하는 것이 Rh Immune Globulin (RhIG) 투 여 적응증을 구분하고 산전위험도를 평가하는데 매우 중요하다[4]. 해외에서는 항-G에 관한 수혈 부작용[5]과 태아신생아용혈성질환[3,4]에 관한 보고가 있었지만, 국내에서는 현재까지 보고가 없었다. 이에 저자들은 비예기항체 동정검사 상, 처음에는 항-D와 -C 복합항체가 의심되었으나 이중흡착 및 해리법을 이용하여 국내에서 최초로 항-G 항체를 동정하였기에, 본 증례를 문헌고찰 과 함께 보고하는 바이다.

\section{증 례}

33 세의 임신 12 주의 여성이 산전관리를 위해 내원하였다. 환자는 내원 3년 전 유산을 한 과거 력이 있었으며, 당시 RhIG를 투여 받은 것 외에 는 특이병력 및 수혈력은 없었다. $\mathrm{ABO}, \mathrm{D}$ 혈액형 검사에서는 $\mathrm{O}, \mathrm{D}$ 음성이었으며 $\mathrm{Rh}$ 표현형은 ce 임을 미세원주응집법으로 확인하였다. Seo 등[6] 이 보고한 방법으로 실시한 $R H D$ 유전자 검사에 서 프로모터, 인트론 4, 엑손 7 그리고 엑손 10 에 대한 $R H D$ 특이 유전산물을 관찰할 수 없어 $R H D$ 유전자의 전체 결손에 의한 $\mathrm{RhD}$ 음성으로 확인 되었다. 함께 내원한 남편은 $\mathrm{O}, \mathrm{D}$ 양성이었으며 $\mathrm{Rh}$ 표현형은 $\mathrm{CDe}$ 이었다. 간접항글로불린 검사에 서 4+로 양성 소견을 보였다. ID-Diacell I, II (DiaMed, Cressier-sur-Morat, Switzerland)를 이용한
비예기항체 선별검사에서는 선별혈구 I (CDe/ $\mathrm{CDe})$ 에서 $3+$, 선별혈구 II $(\mathrm{cDE} / \mathrm{cDE})$ 에서 $2+$ 로 양성소견을 보였다. 비예기항체 동정검사는 LISS/ Coombs card와 함께 동정혈구로 ID-DiaPanel 1-11 (DiaMed, Cressier-sur-Morat, Switzerland)를 이용 하여 항-C와 항-D 특이성을 갖는 항체가 확인되 었다(Table 1). 비예기항체 동정검사 상, $\mathrm{C}$ 항원 일배체와 이배체 모두에 $2+, \mathrm{D}$ 항원에 trace에서 $1+$ 의 응집반응을 보였다. 항-G 항체를 동정하기 위한 이중흡착 및 해리법은 ROr (cDe/cde, $\mathrm{D}+\mathrm{G}+$ $\left.\mathrm{C}^{-}\right)$과 r'r (Cde/cde, $\mathrm{C}+\mathrm{D}-\mathrm{G}+$ ) 표현형의 혈구를 이용하여 시행하였다(Fig. 1, Table 2).

첫째, 항-G 항체의 유무를 확인하는 과정은 다 음과 같았다. 환자의 혈청을 ROr (cDe/cde) 혈구를 이용하여 흡착시킨 뒤 iMR ELU-KIT (미르싸이 텍, 서울, 한국)를 이용하여 해리함으로써, 환자 혈청에 존재할 수 있는 항-C 항체가 제거된 일차 용출액을 얻었다. 일차 용출액과 r'r (Cde/cde) 혈 구를 이용하여 흡착 및 해리하여 항-D 항체가 제

Table 1. Antibody identification results of the patient's serum

\begin{tabular}{lcccccc} 
& \multicolumn{7}{c}{ Rh-hr } & & LISS/ \\
Panel cell & \multicolumn{7}{c}{ coombs } \\
\cline { 2 - 6 } & D & C & E & c & e & \\
\hline 1 & + & + & 0 & 0 & + & $2+$ \\
2 & + & + & 0 & 0 & + & $2+$ \\
3 & + & 0 & + & + & 0 & + \\
4 & 0 & + & 0 & + & + & $2+$ \\
5 & 0 & 0 & + & + & + & - \\
6 & 0 & 0 & 0 & + & + & - \\
7 & 0 & 0 & 0 & + & + & - \\
8 & + & 0 & 0 & + & + & $+/$ \\
9 & 0 & 0 & 0 & + & + & - \\
10 & 0 & 0 & 0 & + & + & - \\
11 & 0 & 0 & 0 & + & + & - \\
Auto & & & & & & - \\
\hline
\end{tabular}




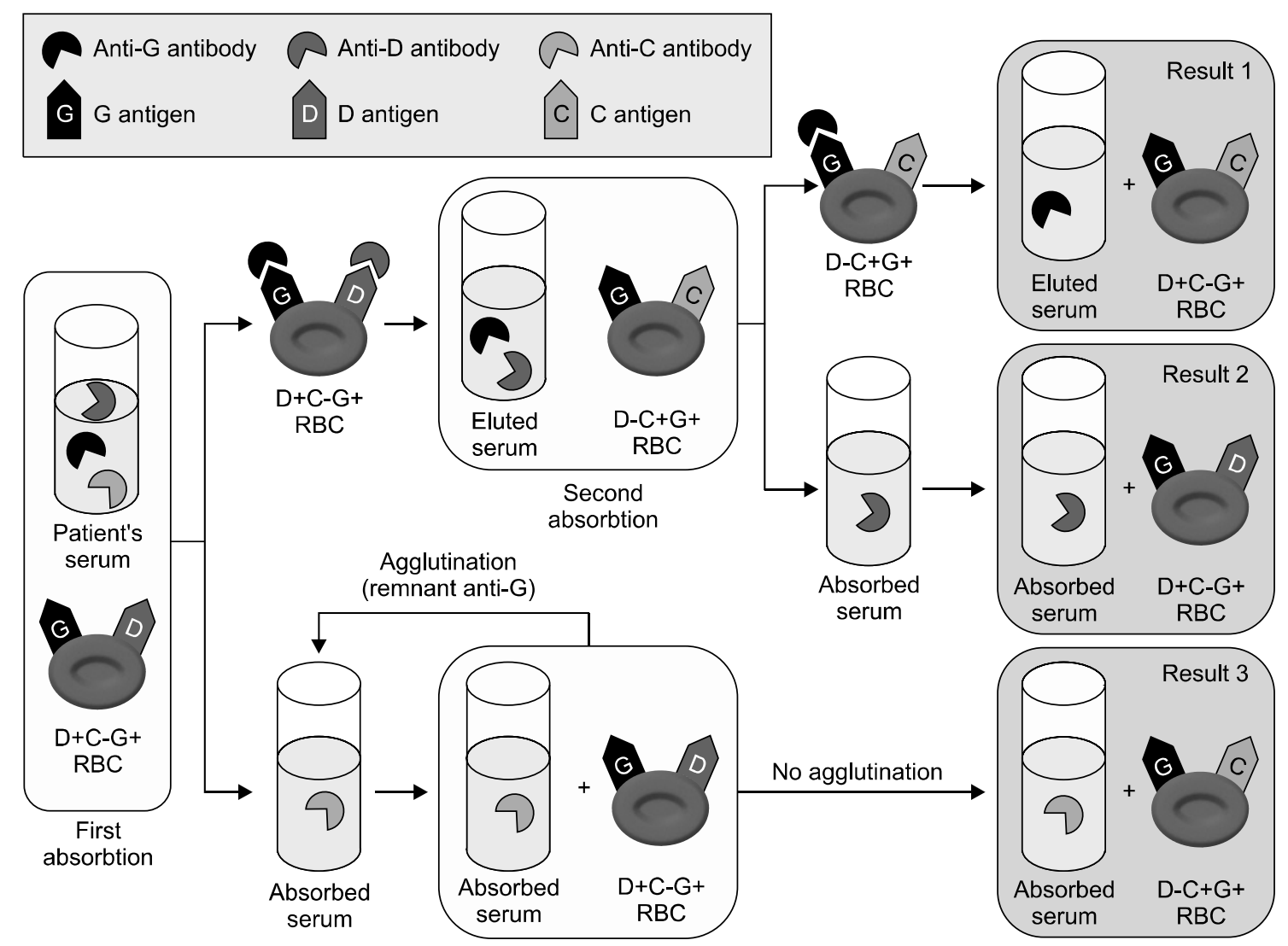

Fig. 1. Anti-G antibody identification process.

거된 이차 용출액을 얻었다. 2 차 용출액과 r'r (Cde/cde) 혈구가 $3+$ 의 항원-항체 반응을 보여 항-G 항체를 동정하였다. 둘째, 항-D 항체의 동시 존재 가능성을 확인하기 위해 일차 용출액과 r'r (Cde/cde) 혈구를 이용한 흡착을 시행한 후, 흡착 후 남은 일차 용출액과 ROr (cDe/cde) 혈구를 반응 시켰다. 본 증례에서 환자는 음성반응을 나타내 었기에 항-D 항체는 존재하지 않는 것으로 판단 하였다. 셋째, 항-C 항체의 동시 존재 가능성을 확인하기 위해 ROr (cDe/cde) 혈구를 이용한 흡착 후 환자의 혈청을 R0r (cDe/cde) 혈구와 반응시켰
다. 이 과정에서 반응이 있다면 환자 혈청 내 과량 의 항-G 항체가 존재하여 흡착을 위해 첨가한 $\mathrm{R} 0 \mathrm{r}$ (cDe/cde) 혈구와 반응을 하지 못한 잉여의 항-G 항체가 남아있음을 추정할 수 있다. 본 증례에서 환자는 $3+$ 의 반응을 나타내었기에 추가로 $\mathrm{R} 0 \mathrm{r}$ (cDe/cde) 혈구를 이용하여 2회의 흡착을 더 시행 하였다. ROr (cDe/cde) 혈구와 반응성이 음전된 것 을 확인하고 난 후, 해당 혈청과 r'r (Cde/cde) 혈구 를 반응시켰고 음성반응을 나타내어 항-C 항체는 존재하지 않는 것으로 판단하였다.

한편, 항글로불린법을 이용한 항-G 항체의 역 
Table 2. Interpretation of results and suggested treatment to prevent $\mathrm{D}$ alloimmunization according to the serum treatment process

\begin{tabular}{|c|c|c|c|c|c|}
\hline $\mathrm{RBC}$ antigen & $\mathrm{D}+\mathrm{C}-\mathrm{G}+$ & $\mathrm{D}+\mathrm{C}-\mathrm{G}+$ & $\mathrm{D}-\mathrm{C}+\mathrm{G}+$ & \multirow{2}{*}{ Interpretation } & \multirow{2}{*}{ Prophylactic RhIG } \\
\hline Serum treatment process & $\mathrm{I}$ & II & III & & \\
\hline \multirow[t]{5}{*}{ Results } & Positive & Positive & Positive & Anti-G, -D, -C & Not needed \\
\hline & Positive & Positive & Negative & Anti-G, -D & Not needed \\
\hline & Positive & Negative & Negative & Anti-G (in this case) & Needed \\
\hline & Positive & Negative & Positive & Anti-G, -C & Needed \\
\hline & Negative & Positive & Positive & Anti-D, -C & Not needed \\
\hline
\end{tabular}

Serum treatment process I, 1) $D+C-G+$ absorption 2) Elution 3) $D-C+G+$ absorption 4) Elution; Serum treatment process II, 1) $\mathrm{D}+\mathrm{C}-\mathrm{G}+$ absorption 2) Elution 3) $\mathrm{D}-\mathrm{C}+\mathrm{G}+$ absorption 4) Remnant serum; Serum treatment process III, 1) $\mathrm{D}+\mathrm{C}-\mathrm{G}+$ absorption 2) Remnant serum.

Abbreviation: RhIG, Rh Immune Globulin.

가는 환자가 임신 12 주에 처음 내원하여 시행하 였을 때는 1:8로 측정되었으나, 임신 18주에는 $1: 32$ 로 측정되었다. 2 주 뒤에 항-G 항체 제거를 위한 혈장교환술의 시행가능성을 염두에 두고 다 시 항체 역가 검사를 시행하였는데, 1:8로 측정되 었다. 일관되지 못한 항체 역가의 원인을 파악하 였더니 기존에 본원에서 시행하는 $\mathrm{Rh}$ 항체 역가 검사에 사용되는 검사용 혈구는 $\mathrm{RhCE}$ 를 고려하 지 않고 D 항원 양성 혈구 중 선별하여 사용하고 있었는데, $\mathrm{CDe}$ 혈구로 다시 검사했더니 항체 역 가가 1:32로 측정되었다. 이에 임신 22주부터는 $\mathrm{CDe}$ 혈구와 $\mathrm{CcDEe}$ 혈구를 활용하여 두 가지 방 법으로 함께 보고하였고, 각각 1:32과 1:8로 사용 하는 혈구에 따라 항체 역가가 4배까지 상이하게 측정되는 것이 확인되었다.

산과적 추적 관찰로는 임신 18 주부터 2 3주 간격으로 태아 중간대뇌동맥 도플러 검사를 시행 하였으며, 임신 28주에 시행한 중간대뇌동맥의 최 대수축속도(peak systolic velocity)는 $34.4 \mathrm{~cm} / \mathrm{sec}$ 로 정상 범위였고, 초음파 검사에서 태아수종(fetal hydrops)가 의심되는 소견은 관찰되지 않았다.

\section{고 찰}

그간 보고된 61 개의 $\mathrm{Rh}$ 항원들 중 $\mathrm{D}$ 항원이 가 장 임상적으로 중요하며, 그 다음으로는 $\mathrm{C}, \mathrm{c}, \mathrm{E}$, $\mathrm{e}$ 으로 알려져 있다. 그 외 여러 항원 중 $\mathrm{G}$ 항원은 국제수혈학회(ISBT) 명명법에 의하여 RH12다[7]. $\mathrm{G}$ 항원은 $R H G$ 라고 특별히 명명된 유전자의 산 물이 아니고, $R H D$ 혹은 $R H C E^{\star} \mathrm{Ce}$ 엑손 2 의 산물 이다[2]. G 항원은 C 또는 D 항원이 양성인 적혈 구에는 모두 존재하므로, 백인의 $85 \%$, 아프리카 인의 $92 \%$ 에서 발현된다고 보고되었다[7].

$\mathrm{D}$ 음성자의 비예기항체 동정검사에서 항-D와 항-C의 복합항체가 의심되는 경우 항-G 항체를 감별해야 하는데, 한국인에서는 그간 보고되지 않 았다. 이는 한국인이 서구인에 비해 D 음성자의 비율이 극히 낮고[8], 수혈 시에는 항-D 및 항-C 복합항체와 항-G 항체의 감별이 필수적이지 않 으며[3], 정확한 항-G 항체의 동정을 위해서는 이 중흡착 및 해리법을 시행해야 하기 때문으로 추 정된다[3,4,9]. 본 증례는 D 양성 태아가 수태되었 을 것으로 추정되는 $\mathrm{D}$ 음성 산모의 혈청에 존재 
하는 비예기항체였기 때문에, 향후 수혈뿐만 아 니라 신생아태아용혈성빈혈을 예방하기 위해 정 확한 항체의 동정이 임상적으로 필요한 상황이었 기 때문에 Fig. 1에서 보여준 것과 같이 이중 흡착 및 해리법을 시행하여 항-G 항체를 동정하였다. 저자들은 모든 D 또는 C 항원 양성 혈구에 양성 반응을 보이고 D 항원보다 C 항원 양성 혈구에 더 강하게 반응하는, 전형적인 항-G 항체의 반응 양상을 확인할 수 있었다(Table 1)[3,10].

항-G는 항-D와 항-C 복합항체보다 신생아태아 용혈성빈혈을 유발할 가능성이 낮고, 발생시에도 일부 보고를 제외하고는[9,11] 출생 후 광선치료 를 요하는 정도의 경한 증상이 대부분인 것으로 보고되었다[3,4]. 따라서, 본 증례는 항-G 항체의 역가를 감소시키기 위해 혈장교환술 같은 적극적 인 조치를 취하기 보다 $\mathrm{CDe}$ 및 $\mathrm{CcDEe}$ 표현형의 혈구를 이용하여 항체 역가를 2주 간격으로 모니 터링하고, 산부인과 초음파 검사를 통하여 태아 중간대뇌동맥 도플러 검사로 태아의 빈혈을 예측 하고, 태아수종 등의 발생 여부를 추적 관찰하고 있다. 한편, 임신 후기와 분만직후에는 추가로 항-D 항체의 발생가능성을 고려하여 RhIG 투약을 계 획하고 있다.

태아가 태아신생아용혈성질환에 이환될 위험 이 있을 것으로 평가된 경우, 주기적으로 태아의 중간대뇌동맥 도플러 초음파 검사를 확인하고 산 모의 혈중 항체의 역가를 모니터링하게 된다. 보편 적으로 사용되는 항체 역가에 대한 치명적인 역치는 8 32정도로 알려져 있다[12]. 하지만 Jernman 등[9] 은 심각한 태아신생아용혈성질환을 일으킨 항-C와 항-G 복합항체의 역가가 1:8이었으며, 항-G 항체 역가는 1 에 불과하였던 것을 근거로 항-G 항체의 역가는 다른 항체들에 비해 태아신생아용혈성질 환을 예측하는 데 있어 신뢰도가 떨어지는 것으 로 보고한 바 있다. 따라서, 항-G 항체 역가의 역
치를 설정하고 이를 임상적으로 활용하기 위해서 는 추가 연구가 필요할 것으로 사료되었다.

항-G 항체의 역가를 측정할 때 주의할 점은 D 와 $\mathrm{C}$ 항원의 양의 차이에 따라 역가가 변할 수 있어 동일한 RhCE 표현형의 적혈구를 사용해야 만 일관된 역가 모니터링이 가능하다는 것이다. 본 증례에서 저자들은 여러 동정용 혈구를 이용 하여 항-G 항체의 역가를 측정해 보았는데, $\mathrm{CDe}$ 의 경우에는 $1: 32, \mathrm{CcDEe}$ 의 경우에는 $1: 8$ 로 상당 히 다르게 측정되었다. 환자와 남편의 혈액형으 로 추론되는 태아의 $\mathrm{Rh}$ subgroup은 $\mathrm{CcDe}$ 로, 개별 증례마다 가장 합당한 $\mathrm{RhCE}$ 표현형의 혈구를 사 용한다면 가장 이상적이라고 할 수 있겠지만 검 사실 운영의 측면에서 모든 증례에 이를 적용하 기는 어려운 실정이다. 이에 저자들은 국내에서 가장 빈도가 높은 $\mathrm{Rh}$ 표현형인 $\mathrm{CDe}$ 와 $\mathrm{CcDEe}$ 표 현형의 혈구[8]를 이용하는 방안을 차선의 방법 으로 선택하였다. 이에, 일관된 모니터링을 위해 두 종류의 적혈구를 사용하여 얻은 항-G 항체의 역가를 함께 보고하고 있다.

항-D와 항-C의 복합항체가 의심되는 D 음성 산모를 대상으로 흡착 및 해리법을 시행한 후향 적 연구들에 따르면, 항-D 항체 없이 항-G 항체가 존재하여 $\mathrm{RhIG}$ 의 예방적 투여가 필요한 경우가 $21.9 \%$ (16/73) 28\% (2/7)에 이르는 것으로 보고된 바 있다 $[13,14]$. 지금까지 국내에서는 산모에서 항-D 와 항-C 항체의 특이성을 동시에 갖는 항체가 동 정되었을 때 항-G 항체를 감별한 문헌보고는 없 었다. $\mathrm{D}$ 와 $\mathrm{C}$ 항원에 양성반응을 보이더라도, 흡 착 및 해리법을 이용한 비예기항체 동정검사에서 항-D 항체가 없이 항-G 항체만 존재하는 것으로 확인된 경우에는 향후 D 항원에 대한 감작을 방 지하기 위한 예방적 RhIG 투여가 필요하다. 본 증례는 항-G 항체만이 단독으로 생성되었고, 남 편이 $\mathrm{CDe}$ 임을 고려하여 예방적 $\mathrm{RhIG}$ 투여를 권 
장하였다.

$\mathrm{D}$ 음성자가 적은 우리나라에서는 항-G 항체가 발생할 확률이 낮아 서구에 비해 인식이 부족한 상황이다. 항-G 항체가 동정된 경우 항-D와 항-C 의 복합항체인 경우와 달리 태아신생아용혈성질 환의 빈도 및 중증도가 낮고, $\mathrm{RhIG}$ 투여가 필요 하다는 점이 다르다[3,4]. 따라서, 본 증례에서와 같이 $\mathrm{D}$ 음성 산모가 항-D와 항-C의 복합항체가 의심될 경우에는 이중 흡착 및 해리법을 시행하 여 항-G 항체를 감별하는 것이 필수적이다.

\section{요 약}

항-G 항체는 D 또는 $\mathrm{C}$ 항원 양성 적혈구와 응 집반응을 보여, 비예기항체 동정검사 시 항-D와 $-\mathrm{C}$ 복합항체 등과 혼동을 초래할 수 있다. 산모가 항-G 항체를 갖는 경우, 항-D와 -C 복합항체를 가 진 산모와 다른 수준의 산전관리 및 RhIG 투여가 필요하므로 정확한 감별이 필수적이다. 저자들은 $\mathrm{D}$ 음성 산모에서 항-D와 항-C 복합항체가 먼저 의심되었지만 이중 흡착 및 해리시험으로 항-G 항체를 동정하여 보고하는 바이다. 33세 D 음성 산모는 ce표현형인데, 내원 3년 전에 유산 후 $\mathrm{RhIG}$ 를 투여하였고, 남편의 표현형은 $\mathrm{CDe}$ 였다. 비예기항체 동정검사 상, $\mathrm{C}$ 항원 일배체와 이배 체 모두에 $2+, \mathrm{D}$ 항원에 trace에서 $1+$ 의 응집반 응을 보였고, R0r (cDe/cde)과 r'r (Cde/cde) 표현형 의 혈구를 이용한 이중흡착 및 해리법으로 항-G 를 동정하였다. 현재 환자는 $\mathrm{CDe}$ 혈구와 $\mathrm{CcDEe}$ 혈구를 활용한 항-G 항체의 역가 측정 및 태아 중간대뇌동맥 도플러 검사를 통하여 산전모니터 링 중이고, 태아에게 특이소견 없이 정상임신을 유지하는 중이다.

\section{References}

1. Allen FH Jr, Tippett PA. A new Rh blood type which reveals the Rh antigen G. Vox Sang 1958;3:321-30

2. Eva Q. Immunohematology. 3rd ed. Raritan: Wolters Kluwer, 2010:144

3. Das S, Shastry S, Murugesan M, B PB, Shastry S. What is it really? Anti-G or anti-D plus anti-C: clinical significance in antenatal mothers. Indian J Hematol Blood Transfus 2017;33: 259-63

4. Yousuf R, Mustafa AN, Ho SL, Tang YL, Leong CF. Anti-G with concomitant anti-C and anti-D: a case report in a pregnant woman. Asian J Transfus Sci 2017;11:62-4

5. Vamvakas EC, Pineda AA, Reisner R, Santrach PJ, Moore SB. The differentiation of delayed hemolytic and delayed serologic transfusion reactions: incidence and predictors of hemolysis. Transfusion 1995;35:26-32

6. Seo MH, Won EJ, Hong YJ, Chun S, Kwon JR, Choi YS, et al. An effective diagnostic strategy for accurate detection of $\mathrm{RhD}$ variants including Asian DEL type in apparently RhD-negative blood donors in Korea. Vox Sang 2016;111:425-30

7. Mark KF; American Association of Blood Banks. Technical manual. 18th ed. Bethesda, Maryland: American Association of Blood Banks, 2014:318

8. Hwang YS. Haplotype frequencies of gene Loci in Koreans. Korean J Blood Transfus 1996;7:233-40

9. Jernman R, Stefanovic V, Korhonen A, Haimila $\mathrm{K}$, Sareneva I, Sulin K, et al. Case report: severe hemolytic disease of the fetus and newborn due to anti-C+G. Immunohematology 2015;31:123-7

10. Lenkiewicz B, Zupańska B. Clinical significance 
of anti-G. Transfus Med 2002;12:221

11. Trevett TN Jr, Moise KJ Jr. Twin pregnancy complicated by severe hemolytic disease of the fetus and newborn due to anti-G and anti-C. Obstet Gynecol 2005;106:1178-80

12. Schwartz J, Padmanabhan A, Aqui N, Balogun RA, Connelly-Smith L, Delaney M, et al. Guidelines on the use of therapeutic apheresis in clinical practice-evidence-based approach from the writing Committee of the American Society for Apheresis: the seventh special issue. J Clin Apher 2016;31:149-62

13. Maley M, Babb R, Chapman CE, Fitzgerald J, Cavanagh G. Identification and quantification of anti-D, -C and -G in alloimmunized pregnant women. Transfus Med 2001;11:443-6

14. Shirey RS, Mirabella DC, Lumadue JA, Ness PM. Differentiation of anti-D, $-C$, and -G: clinical relevance in alloimmunized pregnancies. Transfusion 1997;37:493-6 